\title{
The Impact of Metacognitive Online Reading Strategies on Online Reading Disposition of Saudi EFL Learners
}

\author{
Eyhab T. Yaghi \\ English Department, The Deanship of Common first year \\ Majmaah University, Saudi Arabia \\ Email: e.yaghi@mu.edu.sa
}

Received: $10 / 18 / 2020$

Accepted: 3/7/2021

Published: 4/26/2021

\begin{abstract}
The scientific knowledge related to online reading dispositions and factors affecting the occurrence of these dispositions is limited. Therefore, this treatise aims at studying the impact of metacognitive online reading strategies on online reading dispositions. To achieve this goal, the mixed method was employed using questionnaires and semi-structured interviews. Students' responses were keyed to AMOS software. The statistical analysis has shown students' preference for utilizing support strategies to tackle the problems they might face while they engage with online materials. Reflection, as a disposition, was the most frequently reported by students through their responses to the questionnaires. Further, the results confirmed the impact of metacognitive online reading strategies on online reading dispositions, which was the aim of this paper. These findings provide a holistic understanding of the nature of the relationship between metacognition and dispositions, paving the way for further research that touch other aspects of online reading dispositions.
\end{abstract}

Keywords: Online reading, metacognition, dispositions, reading strategies, Saudi EFL learners

Cite as: Yaghi, E. T. (2021). The Impact of Metacognitive Online Reading Strategies on Online Reading Disposition of Saudi EFL Learners. Arab World English Journal (AWEJ) Special Issue on Covid 19 Challenges (1) 364 -380. DOI: https://dx.doi.org/10.24093/awej/covid.27 
Arab World English Journal (AWEJ) Special Issue on Covid 19 Challenges April 2021

The Impact of Metacognitive Online Reading Strategies on Online Reading

Yaghi

\section{Introduction}

People become more dependent on Internet as a source of acquiring information and even as a learning tool. Therefore, educational institutes have started to offer and deliver their courses digitally via Internet, and many instructors use the Internet as an instrument to hold their courses and interact with their students. Consequently, these changes force students and people who work in the field of education to employ different strategies and skills to cope with the updating nature of internet information.

As a result, EFL learner face some obstacles when they deal with materials written in English. To tackle these difficulties, students employ various strategies to comprehend vague words and gain the optimal meaning from the texts (Marboot, Roohani, \& Mirzaei, 2020). Metacognitive reading strategies provide an aid for students to overcome obstacles they might face while dealing with texts displayed on the Internet.

Digital texts cause students to act in different ways, showing different behaviors while engaging in reading English materials offered on the Internet. However, their dispositions vary from one student to another according to different factors (Dewi \& Sahiruddin, 2020).

There is a shortage in research that examine the intended variables and what is the relationship between them. Therefore, in order to reach a full understanding of the employed metacognitive reading strategies and the potential dispositions that might take place while engaging with digital materials, a research was conducted on this area which would give further explanation for the nature of this relationship, also, it would try to delineate theoretical thinking about this relationship.

\section{Literature Review}

\section{Metacognitive Online Reading Strategies (MORS)}

Sheorey and Mokhtari (2001) have placed metacognitive reading strategies into three categories, namely, global, problem-solving and support strategies. Global strategies help learners monitor their reading, review content, check its appropriateness of the content, observe text's characteristics, such as length and organization, and anticipate the text meaning. Problemsolving strategies are actions that readers take while working straightforwardly with the content, particularly when the content becomes troublesome. These strategies involve inferring from obscure words, modifying the reading rate, settling the conflicting data, and rereading the text to promote comprehension. Support strategies are what readers use to expand comprehension, for example, utilizing a dictionary, taking notes, shedding light on certain information, or translating from one's first language to the targeted language.

Anderson (2003) compared ESL and EFL students' different uses of metacognitive online reading strategies, using the Online Survey of Reading Strategies (OSORS), which was specifically created for his study, based on the Survey of Reading Strategies (SORS). The adapted Online SORS (OSORS) consists of 38 items that measure metacognitive reading strategies. The items are subdivided into three categories: global reading strategies (18 items), problem solving strategies (11 items), and support strategies (nine items). The findings of this study revealed no differences between participants and in the use of global and support reading 
Arab World English Journal (AWEJ) Special Issue on Covid 19 Challenges April 2021

The Impact of Metacognitive Online Reading Strategies on Online Reading

Yaghi

strategies between the two groups. Anderson's paper has an important role in the literature by being the first study on online strategy uses of L2 readers.

\section{Online Reading Dispositions (ORDS)}

According to Claxton* and Carr (2004), learning requires capability, however, capability alone is not sufficient for learning to occur, especially in academic settings. Learning also takes specific dispositions, or affective variables, which, according to- Boggiano, Main, and Katz (1988), is a "domain of human attributes not attributed to knowledge, skill, or behavior" (p. $5)$.

Furthermore, Carr and Claxton (2002) defined disposition as a "tendency to edit, select, adapt, and respond to the environment in a recurrent, characteristic kind of way" (p.3). Basically, a learning disposition is a pattern of behaviors, situated in the context of the environment that when recognized and developed by those who can manipulate the environment, may lead to gaining knowledge, skills, and understandings. Thus, while online reading comprehension involves specific skills and strategies, there exists the likelihood of affective factors that determine how these skills and strategies are used.

Five dispositions were chosen from three sources: 1) a review of the literature; 2) preliminary results of verbal protocol analysis of seventh-grade students' online reading (Zawilinski et al., 2007); and 3) classroom observations that took place during a study investigating the development of the Internet Reciprocal Teaching model- (Leu et al., 2005). These included: persistence, flexibility, collaboration, reflection, and critical stance. Since positive dispositions can lead to effective learning, it was thought that these five dispositions were likely to affect online reading comprehension.

Persistence refers to the firm continuance in a course of action during online reading, despite ongoing difficulties. Online reading is often challenging- (Eagleton \& Dobler, 2007). It requires rapid, ongoing decision-making, evaluation of those decisions, and frequent revisions to initial decisions regarding what and where to read as readers locate, evaluate, synthesize and communicate information (Coiro, 2009). Students may give up when they do not find the information they seek.

Flexibility refers to the learner being able to transfer skills to novel situations and to apply new approaches when the initial one is unsuccessful. When reading online, students require diverse ways of thinking about conceptual and procedural knowledge (Lawless \& Schrader, 2008).

Collaboration refers to students being able to work together in online environments to solve problems. While offline comprehension has long been operationalized as an individual task, it is becoming evident that learning in the $21^{\text {st }}$ century requires greater collaboration among students.

Reflection refers to thinking about one's own thinking process while continually looking for more effective and efficient ways to expand these abilities. Online reading comprehension 
Arab World English Journal (AWEJ) Special Issue on Covid 19 Challenges April 2021

The Impact of Metacognitive Online Reading Strategies on Online Reading

Yaghi

requires continual reflection when students monitor and evaluate how they locate, evaluate, synthesize and communicate information (Coiro, 2007).

Finally, critical stance refers to having a healthy skepticism regarding the information that the student is considering. Evaluation of online texts also requires this critical eye (Fitzgerald, 2000). There are many challenges that students face while using the Internet since the texts are not vetted, are multimodal, subjected to manipulation, and can be authored by anyone (Tate \& Alexander, 1996).

Carr and Claxton (2002) suggested that learning is an interaction of capabilities and dispositions. Studies investigating the capabilities of students while reading online are emerging, e.g. (Castek, Bevans-Mangelson, \& Goldstone, 2006; Coiro, 2007), however, little is known regarding the specific dispositions that strengthen these skills (Yaghi \& Abdullah, 2020).

\section{Problem Statement}

The body of research has investigated the students' usage of metacognitive online reading strategies in different places around the globe, however, there is a literary gap investigating the disposition students show while reading digital texts. Furthermore, the impact of metacognitive online reading strategies on students' online reading dispositions has not been studied before. Therefore, the aim of this paper is to understanding this issue, seeking to map out a conceptual thinking of this relationship.

\section{Questions of the Study}

a) What are the most and least used metacognitive online reading strategies (MORS) employed by Saudi EFL learners?

b) What are the most and least frequent online reading dispositions (ORDS) of the Saudi EFL learners?

c) Does MORS impact ORDS?

\section{Methods}

This paper employed a mixed research (quantitative-qualitative). Therefore, the tool utilized a questionnaire for the quantitative stage and a semi-structured interview for the qualitative stage. The overall goal of mixed-methods research (combining qualitative and quantitative research components) is to expand and strengthen a study conclusion and, therefore, contribute to the published literature. The mixed-method added value by increasing the validity of the findings, informing the collection of the second data source, and assisting with knowledge creation (Hurmerinta-Peltomäki \& Nummela, 2006).

\section{Participants}

The research was aimed at students admitted in the Preparatory Year Deanship (PYD), at Majmaah University, in the second semester of the academic year 2019/2020. To achieve the goal of this paper, a sample 301 of PYD students was used. Furthermore, semi-structured interviews were conducted with five students to explore their points of view about the relationship intended to be studied in this paper. 
Arab World English Journal (AWEJ) Special Issue on Covid 19 Challenges April 2021

The Impact of Metacognitive Online Reading Strategies on Online Reading

Yaghi

\section{Instruments}

The study employed the metacognitive online reading strategies questionnaire OSORS to explore students' tendency toward using and employing MORS. It has been adapted from Anderson's MORS questionnaire (Anderson, 2003). (Anderson, 2003) describes reading as "an active, fluent process that involves the reader and the reading material in building meaning" (p.85). The survey originally has 38 items (18 items on global strategies, 11 on problem solving strategies, and 9 items on support strategies).

Furthermore, the dispositions from the online reading comprehension (DORC) questionnaire (O’Byrne \& McVerry, 2009) were adapted for this research, which allowed participants to show the dispositions they might expose while reading online. This questionnaire consists of five main constructs, flexibility, reflection, collaboration, persistence, and critical instance.

Both questionnaires were tools for achieving the goal of the quantitative phase of the paper. The participants were asked to grade questionnaires statements according to Likert scale ( $1=$ strongly disagree, $2=$ disagree, $3=\mathrm{I}$ am not sure, $4=$ agree and $5=$ strongly agree $)$.

Accompanying the results from the quantitative phase, five students were interviewed using a semi-structured interview method. The aim of utilizing semi-structured interviews is to deepen the understanding of the quantitative phase. Also, it would present a clearer view of the relationship among variables since respondents provide direct and honest responses to the interviewer's questions.

\section{Research Procedures}

Students' responses to questionnaires were gathered and keyed them into the AMOS software in order to find out the main statistics and understand the impact of MORS on ORDS. In addition, five students were interviewed as a complement to the qualitative phase.

\section{Results}

\section{Quantitative Phase}

This section addresses the descriptive statistics that answer the questions of the study. It highlights the highest and lowest statements reported by students and focus on the main striking results that would offer more elaboration on the variables and the relationship between them. Question 1: What are the most and least used metacognitive online reading strategies employed by Saudi EFL learners?

Table one demonstrates the mean and standard deviation for each OSORS statement. The value of the mean refers to the frequency of use which ranged from $1=$ strongly disagree to $5=$ strongly agree.

Table 1.The mean and standard deviation of MORS

\begin{tabular}{|c|c|c|c|c|}
\hline & Global Reading Strategies & & $M$ & $S D$ \\
\hline 1 & I have a purpose in mind when I read online. & GRS1 & 2.967 & 1.449 \\
\hline 2 & I participate in live chats with other learners of English. & GRS2 & 2.732 & 1.402 \\
\hline 3 & I participate in live chats with native speakers of English. & GRS3 & 2.679 & 1.412 \\
\hline
\end{tabular}

ISSN: 2229-9327 
Arab World English Journal (AWEJ) Special Issue on Covid 19 Challenges April 2021

The Impact of Metacognitive Online Reading Strategies on Online Reading

Yaghi

$4 \quad$ I think about what I know to help me understand what I read $\quad$ GRS4 3.123

1.429 online

5 I take an overall view of the online text to see what it is about before reading it.

6 I review the online text first by noting its characteristics, like $\quad$ GRS6 $3.073 \quad 1.352$ length and organization.

7 When reading online, I decide what to read closely and what to ignore.

8 I read pages on the Internet for academic purposes.

GRS5 $\quad 3.060 \quad 1.411$

9 I stop from time to time and think about what I am reading online.

10 I try to picture or visualize information to help remember what I read online.

11 I use typographical features like boldface and italics to identify key information.

12 I critically analyze and evaluate the information presented in the online text.

13 I check my understanding when I come across new information.

GRS7 $3.361 \quad 1.314$

GRS8 $\quad 3.132 \quad 1.285$

GRS9 $3.172 \quad 1.329$

GRS10 $3.238 \quad 1.293$

GRS11 $3.228 \quad 1.306$

GRS12 $2.957 \quad 1.245$

GRS13 $3.149 \quad 1.264$

14 I try to guess what the content of the online text is about when I GRS14 $\quad 3.255 \quad 1.309$ read.

15 I check to see if my guesses about the online text are right or $\quad$ GRS15 $\quad 3.046 \quad 1.311$ wrong.

16 I scan the online text beforehand to get a basic idea of whether it will serve my purposes.

17 I read pages on the Internet for fun.

GRS16 $2.974 \quad 1.268$

18 I can distinguish between fact and opinion in online texts.

GRS17 $3.099 \quad 1.319$

GRS18 $3.096 \quad 1.295$

$3.074 \quad 1.332$

\section{Problem Solving Strategies}

19 I critically evaluate the online text before choosing to use the information I read.

20 I read slowly and carefully to make sure I understand what I am reading online.

21 I try to get back on track when I lose concentration.

22 I adjust my reading speed according to what I am reading online.

23 When the online text becomes difficult, I pay closer attention to what I am reading.

24 I use context clues to help me better understand what I am reading online.

25 I paraphrase (restate ideas in my own words) to better understand what I read on- line

26 When I read online, I guess the meaning of unknown words or $\quad$ PSS8 $\quad 3.060 \quad 1.373$ phrases.

$\begin{array}{lll}\text { PSS1 } & 2.997 & 1.413 \\ \text { PSS2 } & 3.222 & 1.325 \\ & & \\ \text { PSS3 } & 3.189 & 1.300 \\ \text { PSS4 } & 3.089 & 1.365 \\ \text { PSS5 } & 3.219 & 1.361 \\ \text { PSS6 } & 3.142 & 1.333 \\ \text { PSS7 } & 3.083 & 1.341 \\ \text { PSS8 } & 3.060 & 1.373\end{array}$


Arab World English Journal (AWEJ) Special Issue on Covid 19 Challenges April 2021

The Impact of Metacognitive Online Reading Strategies on Online Reading

Yaghi

27 I go back and forth in the online text to find relationships

PSS9 $\quad 3.232$

1.359 among ideas.

28 When the online text becomes difficult, I re-read it to increase $\quad$ PSS10 $\quad 3.043 \quad 1.298$ my understanding.

29 I think about whether the content of the online text fits my $\quad$ PSS11 $\quad 3.242 \quad 1.361$ reading purpose.

\section{Support Strategies}

30 I take notes while reading online to help me understand what I read.

31 When the online text becomes difficult, I read aloud to help me understand what I read.

32 I print out a hardcopy of the online text, then underline or circle information to help me remember it.

33 I use reference materials (e.g., an online dictionary) to help me understand what I read online.

34 I use tables, figures, and pictures in the online text to increase my understanding.

35 When reading online, I look for sites that cover both sides of an issue.

36 When reading online, I translate from English into my native language.

37 When reading online, I think about information in both English and my mother tongue.

38 I ask myself questions I like to have answered in the online text.

$\begin{array}{lll}\text { SS1 } & 3.242 & 1.354 \\ \text { SS2 } & 3.308 & 1.320 \\ \text { SS3 } & 3.113 & 1.407 \\ \text { SS4 } & 3.142 & 1.262 \\ \text { SS5 } & 3.334 & 1.275 \\ \text { SS6 } & 3.053 & 1.348 \\ \text { SS7 } & 3.073 & 1.272 \\ \text { SS8 } & 3.325 & 1.292 \\ \text { SS9 } & 3.179 & 1.330 \\ & 3.196 & 1.317\end{array}$

Note. The abbreviations used in this table are: $\mathrm{M}=$ mean, $\mathrm{SD}=$ standard deviation, $\mathrm{GRS} 1-18=$ global reading strategy items, PSS1-11 = problem-solving strategy items, SS1-9 = support strategy items.

As shown in Table 1 the 302 surveyed students reported using each reading strategy item in the OSORS with varying degrees of frequency. The mean values for individual strategy items ranged from a high of 3.361 to a low of 2.679. The most frequently reported item was item nine, "When reading online, I decide what to read closely and what to ignore" $(\mathrm{M}=3.361)$. This strategy was followed by item 36, "I use tables, figures, and pictures in the online text to increase my understanding" ( $\mathrm{M}=3.334)$ and item 39, "When reading online, I think about information in both English and my mother language" (M=3.325). The strategy with the lowest mean was item five, "I participate in live chats with native speakers of English" $(\mathrm{M}=2.679)$. The second lowest strategy was item four, "I participate in live chats with other learners of English" $(\mathrm{M}=2.732)$, followed by item 14, "I critically analyse and evaluate the information presented in the online text" $(\mathrm{M}=2.957)$. 
Looking at the average of mean values, Table one illustrates that the most used strategies reported by students are the support strategies $(\mathrm{M}=3.196)$ followed by the problem-solving strategies $(M=3.138)$ while global strategies were the least used $(M=3.075)$. Table two discusses the most and the least frequently reported strategies by all participants.

Table 2. The most and least frequently occurring MORS

\begin{tabular}{|c|c|c|c|}
\hline Category & Strategy & Category & Strategy \\
\hline \multicolumn{2}{|r|}{ Most frequent } & \multicolumn{2}{|r|}{ Least frequent } \\
\hline GRS7 & $\begin{array}{l}\text { When reading online, I } \\
\text { decide what to read closely } \\
\text { and what to ignore. }\end{array}$ & GRS3 & $\begin{array}{l}\text { I participate in live chats with } \\
\text { native speakers of English. }\end{array}$ \\
\hline SS5 & $\begin{array}{l}\text { I use tables, figures, and } \\
\text { pictures in the online text to } \\
\text { increase my understanding. }\end{array}$ & GRS2 & $\begin{array}{l}\text { I participate in live chats with } \\
\text { other learners of English. }\end{array}$ \\
\hline SS8 & $\begin{array}{l}\text { When reading online, I think } \\
\text { about information in both } \\
\text { English and my mother } \\
\text { tongue. }\end{array}$ & GRS12 & $\begin{array}{l}\text { I critically analyze and } \\
\text { evaluate the information } \\
\text { presented in the online text. }\end{array}$ \\
\hline SS2 & $\begin{array}{l}\text { When the online text } \\
\text { becomes difficult, I read } \\
\text { aloud to help me understand } \\
\text { what I read. }\end{array}$ & GRS1 & $\begin{array}{l}\text { I have a purpose in mind } \\
\text { when I read online. }\end{array}$ \\
\hline GRS14 & $\begin{array}{l}\text { I try to guess what the } \\
\text { content of the online text is } \\
\text { about when I read. }\end{array}$ & GRS16 & $\begin{array}{l}\text { I scan beforehand the online } \\
\text { text to get a basic idea of } \\
\text { whether it will serve my } \\
\text { purposes. }\end{array}$ \\
\hline
\end{tabular}

Note. The abbreviations used in this table refer to items from global reading strategies (GRS) and support strategies (SS).

Regarding the most frequently used strategies, three of the top five strategies $(60 \%)$ are support strategies and the other two strategies are global reading strategies $(40 \%)$. On the other hand, all five least frequently used strategies belong to global reading strategies.

Question 2: What are the most and least frequent online reading dispositions displayed by Saudi EFL learners?

Table 3. The mean and standard deviation of ORDS

\begin{tabular}{llll}
\hline Reflection & Category & $M$ & $S D$ \\
\hline $\begin{array}{l}\text { When one strategy does not work for finding } \\
\text { information on the Internet I pick another and keep }\end{array}$ & RT1 & 3.159 & 1.285 \\
$\begin{array}{l}\text { trying. } \\
\begin{array}{l}\text { I am always learning new things when using the } \\
\text { Internet. }\end{array}\end{array}$ & RT2 & 3.046 & 1.430
\end{tabular}


Arab World English Journal (AWEJ) Special Issue on Covid 19 Challenges April 2021

The Impact of Metacognitive Online Reading Strategies on Online Reading

Yaghi

When I get stuck looking for something online, I am willing to try new things.

When using the Internet, I try hard to learn new

things.

I am ready to learn new things on the Internet even

when they are hard

When searching online gets tough, I am willing to spend extra time.

I think about the words I choose when I write an email or comment.

It is important to keep your goal in mind when reading online.

I think about how I am reading when I visit websites.

I think about my opinion of a subject when reading websites.

When I choose a website to read, I think back to what

I already know.

I think about what I am doing as I use the Internet.

I make a plan before I use the Internet for assignments.

RT3

3.076

1.319

I ask myself if I am finding what I am looking for on the Internet.

RT4 $\quad 3.040 \quad 1.402$

$\begin{array}{lll}\text { RT5 } & 3.036 \quad 1.370\end{array}$

$\begin{array}{lll}\text { RT6 } & 2.781 \quad 1.388\end{array}$

$\begin{array}{lll}\text { RT7 } & 3.017 \quad 1.438\end{array}$

$\begin{array}{lll}\text { RT8 } & 3.185 & 1.369\end{array}$

$\begin{array}{lll}\text { RT9 } & 3.070 & 1.388\end{array}$

$\begin{array}{lll}\text { RT10 } & 3.129 & 1.398\end{array}$

$\begin{array}{lll}\text { RT11 } & 2.993 \quad 1.376\end{array}$

RT12 $3.156 \quad 1.314$

RT13 $3.123 \quad 1.345$

RT14 $3.103 \quad 1.366$

\begin{tabular}{llll} 
& & 3.065 & 1.37057 \\
\hline Critical Instance & & & \\
\hline I trust the opinions I read on websites. & CS1 & 2.974 & 1.349 \\
Authors tell the truth when writing on the Internet. & CS2 & 2.884 & 1.351 \\
I trust what I read on the Internet. & CS3 & 2.960 & 1.376 \\
You can trust the pictures on websites. & CS4 & 2.755 & 1.359 \\
& & 2.89 & 1.35
\end{tabular}

Collaboration

I enjoy working with classmates when using the Internet.

$\begin{array}{llll}\text { I like doing projects with other people when using the } & \mathrm{CO} 2 & 2.81 & 1.377\end{array}$ Internet.

$\begin{array}{llll}\text { I can work with a partner to solve problems online. } & \text { CO3 } & 2.94 & 1.342\end{array}$

\begin{tabular}{|c|c|c|c|}
\hline \multirow{2}{*}{\multicolumn{2}{|c|}{ Flexibility }} & 2.87 & 1.367 \\
\hline & & & \\
\hline $\begin{array}{l}\text { Solving problems using the Internet often takes } \\
\text { strategies I learned somewhere else. }\end{array}$ & FL1 & 2.84 & 1.348 \\
\hline $\begin{array}{l}\text { Using the Internet requires me to make quick changes } \\
\text { in how I read. }\end{array}$ & FL2 & 2.79 & 1.349 \\
\hline $\begin{array}{l}\text { When searching online, I often have to change the } \\
\text { strategies I have used in the past. }\end{array}$ & FL3 & 2.78 & 1.334 \\
\hline $\begin{array}{l}\text { When reading on the Internet, you have to look at } \\
\text { information by moving between different viewpoints }\end{array}$ & FL4 & 2.83 & 1.379 \\
\hline
\end{tabular}


Arab World English Journal (AWEJ) Special Issue on Covid 19 Challenges April 2021

The Impact of Metacognitive Online Reading Strategies on Online Reading

Yaghi

\begin{tabular}{|c|c|c|c|}
\hline & & 2.80 & 1.354 \\
\hline \multicolumn{4}{|l|}{ Persistence } \\
\hline $\begin{array}{l}\text { When I cannot find what I am looking for on the } \\
\text { Internet, I keep trying. }\end{array}$ & PE1 & 2.92 & 1.362 \\
\hline \multirow{2}{*}{$\begin{array}{l}\text { When I make a mistake when using the Internet, I } \\
\text { keep trying until I get it right. }\end{array}$} & PE2 & 3.02 & 1.388 \\
\hline & & 2.97 & 1.375 \\
\hline
\end{tabular}

Note. The abbreviations used in this table refer to reflection-related items (RT1-14), critical instance-related items (CS1-4), collaboration-related items (CO1-3), flexibility-related items (FL1-4), and persistance-related items (PE1-2).

Table three displays the responses of the 303 surveyed students regarding their online reading dispositions. The most frequently occurring dispositions were ones belonging to the reflection category, with the mean $\mathrm{M}=3.065$, while the least frequently appearing dispositions are those under flexibility category with the average mean $\mathrm{M}=2.801$. Means of individual items ranged from 3.185 (highest) to 2.775 (lowest). The most frequently reported item was "It is important to keep your goal in mind when reading online" while the least frequent item was "You can trust the pictures on websites".

Table 4. The most and least occurring ORDS

\begin{tabular}{|c|c|c|c|}
\hline Category & Disposition & Category & Disposition \\
\hline \multicolumn{2}{|c|}{ Most occurring } & \multicolumn{2}{|c|}{ Less occurring } \\
\hline RT8 & $\begin{array}{l}\text { It is important to keep your goal in } \\
\text { mind when reading online. }\end{array}$ & $\mathrm{CO} 2$ & $\begin{array}{l}\text { I like doing projects with other } \\
\text { people when using the Internet. }\end{array}$ \\
\hline RT1 & $\begin{array}{l}\text { When one strategy does not work for } \\
\text { finding information on the Internet, I } \\
\text { pick another and keep trying. }\end{array}$ & FL2 & $\begin{array}{l}\text { Using the Internet requires me } \\
\text { to make quick changes in how I } \\
\text { read. }\end{array}$ \\
\hline RT12 & $\begin{array}{l}\text { I think about what I am doing as I use } \\
\text { the Internet. }\end{array}$ & RT6 & $\begin{array}{l}\text { When searching online gets } \\
\text { tough, I am willing to spend } \\
\text { extra time. }\end{array}$ \\
\hline RT10 & $\begin{array}{l}\text { I think about my opinion of a subject } \\
\text { when reading websites. }\end{array}$ & FL3 & $\begin{array}{l}\text { When searching online, I often } \\
\text { have to change the strategies I } \\
\text { have used in the past. }\end{array}$ \\
\hline RT13 & $\begin{array}{l}\text { I make a plan before I use the Internet } \\
\text { for assignments. }\end{array}$ & CS4 & $\begin{array}{l}\text { You can trust the pictures on } \\
\text { websites. }\end{array}$ \\
\hline
\end{tabular}

Note. The abbreviations used in this table refer to reflection-related items (RT), critical instancerelated items (CS), collaboration-related items (CO), and flexibility-related items (FL).

Based on Table four, it can be seen that the most occurring dispositions belong to the reflection category $100 \%$. On the other hand, the less occurring dispositions varied between 
Arab World English Journal (AWEJ) Special Issue on Covid 19 Challenges April 2021

The Impact of Metacognitive Online Reading Strategies on Online Reading

Yaghi

those belonging to flexibility, with $40 \%$, while other dispositions were equally distributed, $20 \%$ each, between critical stance, reflection and collaboration.

\section{The Relationship between IV Items and DV Items}

Online Reading Strategies ' Groups among DV Items

The online reading strategies were divided into three groups. Each group was measured separately with the DV. For example, the global reading strategies group (group one) was measured through eight questionnaire items, labeled as GRS2, GRS3, GRS4, GRS7, GRS13, GRS16, GRS17, and GRS18; problem solving strategies group (group two) was measured through eight items, labeled as PSS19, PSS21, PSS22, PSS24, PSS25, PSS26, PSS27, and PSS28; and support strategies group (group three) was measured through six items, labeled as SS30, SS31, SS32, SS33, SS34, and SS35.

\section{Global Reading Strategies (Group One)}

As presented in figure one, the correlation between the IV-GRS and the DV was 0.75. According to the same figure, the standardized parameters estimations have shown that all indicators were statistically significant $(\mathrm{P}<0.001)$. The CFA results also showed that chi-square was significant, at $1432.864(\mathrm{df}=404, \mathrm{P}=0.000, \mathrm{~N}=302)$. The GFI was 0.678 and $\mathrm{RSMEA}=$ 0.092 .

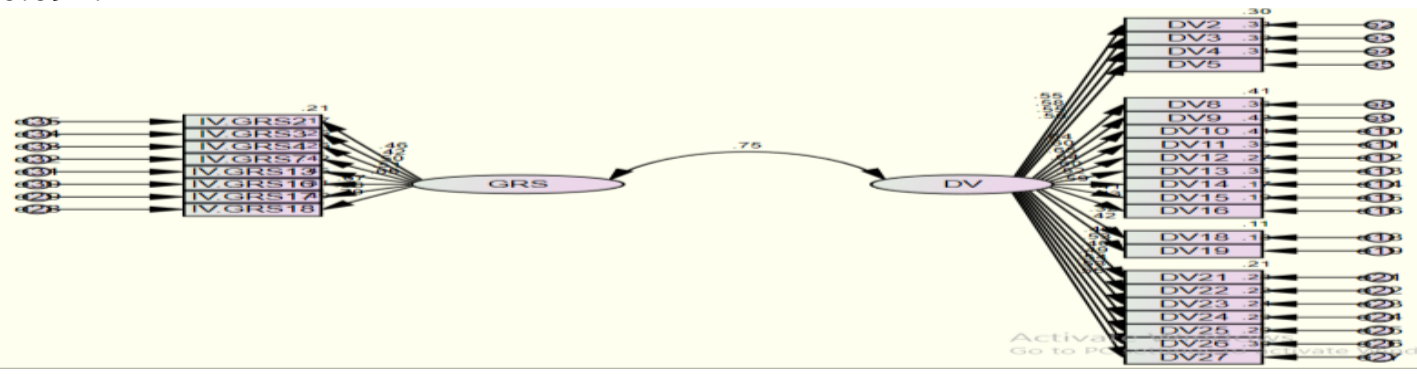

Figure 1. Impact of global reading strategies on online reading dispositions

(b) Problem Solving Strategies (Group Two)

The results of CFA as shown in figure two, indicate that the standardized parameter estimates for all indicators were statistically significant $(\mathrm{P}<0.001)$ and loaded on this factor. Results also indicate that this model fits to the data adequately. As desired, the chi-square goodness-of-fit was statistically insignificant, at $1544.464(\mathrm{df}=4052, \mathrm{P}=0.000, \mathrm{~N}=302)$. The GFI was 0.658 and RSMEA $=0.097$.

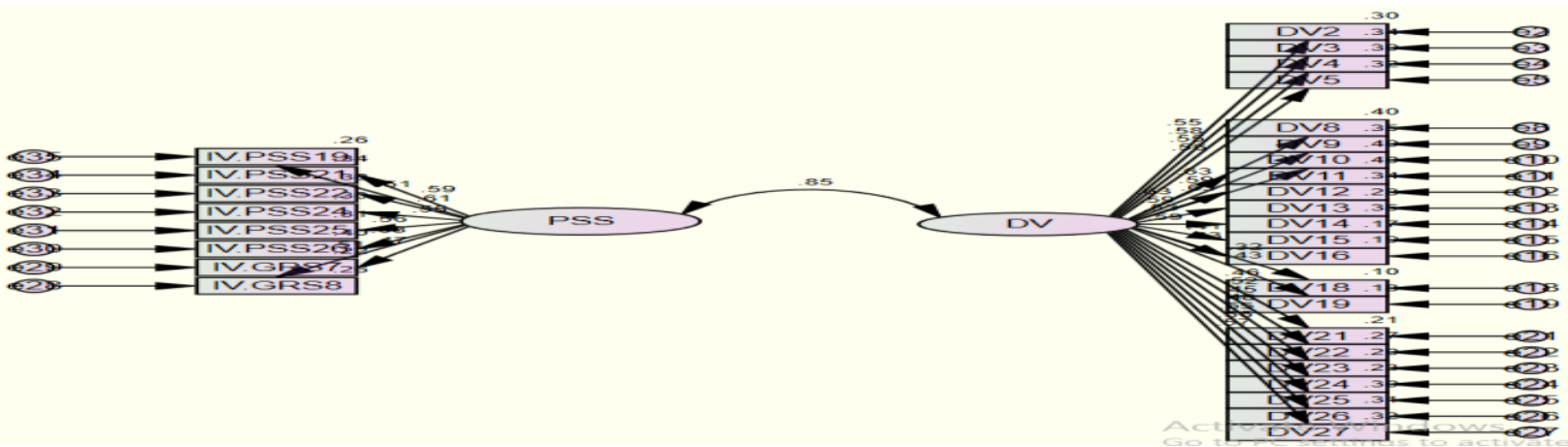

Figure 2. Impact of problem-solving strategies on online reading dispositions Support Strategies (Group Three) 


\section{Arab World English Journal (AWEJ) Special Issue on Covid 19 Challenges April 2021}

The correlation was reported at 0.716. The chi-square goodness-of-fit was statistically insignificant, at $1423.438(\mathrm{df}=3492, \mathrm{P}=0.000, \mathrm{~N}=302)$. The GFI was 0.685 and $\mathrm{RSMEA}=$ 0.101 .

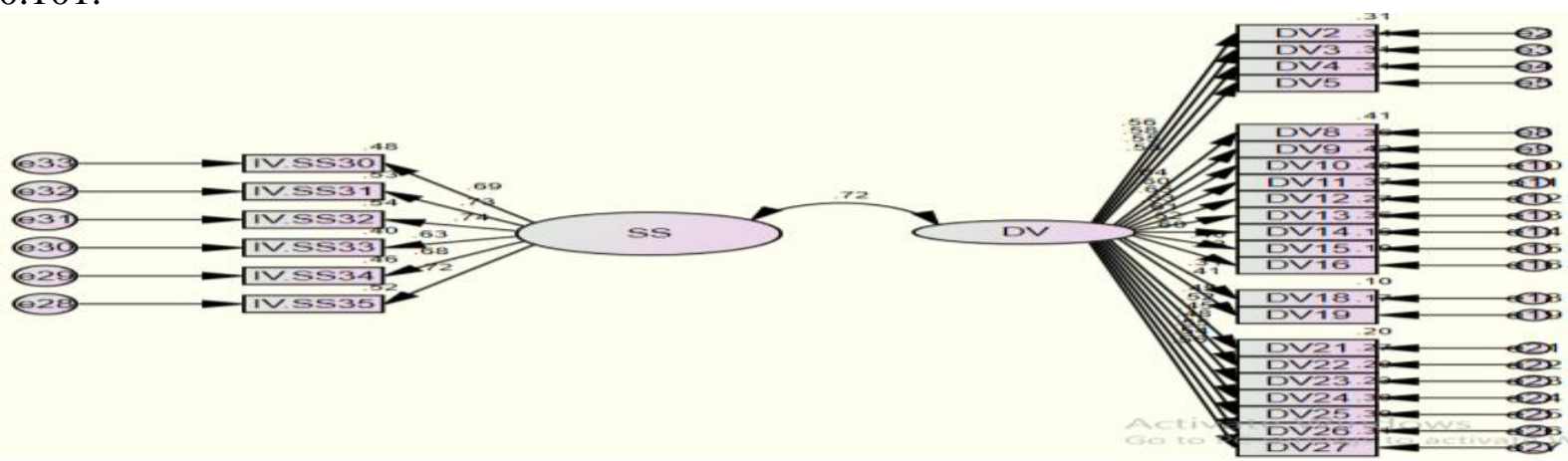

Figure 3. Impact of support strategies on online reading dispositions

To assess the hypothesized relationships between constructs, a bootstrapping sample of 5,000 was applied. Metacognitive online reading strategies $(\beta=0.317, t=7.053, p<0.001)$ were found to positively influence online reading dispositions. In order to determine whether these two exogenous constructs have substantial impact on the endogenous construct, their respective effect size $\left(\mathrm{f}^{2}\right)$ was tested (Hair Jr, Hult, Ringle, \& Sarstedt, 2016). In determining the magnitude of the effect size, Cohen's (1988) guidelines were employed, in which $\mathrm{f}^{2}$ values of $0.02,0.15$, and 0.35 represent small, medium, and large effects, respectively . The results indicated that the metacognitive online reading strategies $\left(f^{2}=0.199\right)$ had substantial and medium effects on online reading dispositions.

Table 5. The impact of MORS on ORDS

$$
\begin{array}{llll}
\text { Path Coefficient } & \text { t-value } & \text { Effect size } & \text { Supported }
\end{array}
$$

\begin{tabular}{lllll}
\hline MORS $\rightarrow$ ORD & 0.317 & $7.053^{* *}$ & 0.199 & No \\
\hline
\end{tabular}

\section{Qualitative Phase}

The sample size of students who were interviewed was five. They were students of varying disciplines of PYD. Table six offers further details in this regard.

\begin{tabular}{lll} 
& & \multicolumn{1}{c}{ Table 6. Students' distribution among disciplines } \\
\hline S/N & Respondents & Discipline \\
\hline 1 & A & Medicine \\
2 & B & Medicine \\
3 & C & Engineering \\
4 & D & Engineering \\
5 & E & Applied Medical Sciences
\end{tabular}

In this phase, five Saudi students (A, B, C, D, and E) of PYD were selected and interviewed to investigate their points of view, as EFL learners, regarding online reading dispositions, the usage of metacognitive online reading strategies, and the impact of metacognitive online reading strategies on online reading dispositions. The respondents' 
Arab World English Journal (AWEJ) Special Issue on Covid 19 Challenges April 2021

The Impact of Metacognitive Online Reading Strategies on Online Reading

Yaghi

interview data were noted verbatim. Table seven reflects the main codes and categories that resulted from the students' interviews.

Table 7. Codes and categories resulted from qualitative analysis

\begin{tabular}{|c|c|c|}
\hline No & Codes & Categories \\
\hline 1 & $\begin{array}{l}\text { Occurring Online reading } \\
\text { dispositions }\end{array}$ & $\begin{array}{ll}\text { - } & \text { Flexible } \\
\text { - } & \text { Collaborative } \\
\text { - } & \text { Persistence } \\
\end{array}$ \\
\hline 2 & $\begin{array}{l}\text { Alternatives to online reading } \\
\text { dispositions }\end{array}$ & $\begin{array}{l}\text { - } \text { Searching different websites. } \\
\text { - } \quad \text { Asking for assistance. }\end{array}$ \\
\hline 3 & Views on online reading dispositions & $\begin{array}{ll}\text { - } & \text { Helpful } \\
\text { - } & \text { Difficult } \\
\text { - } & \text { Need developing } \\
\end{array}$ \\
\hline 4 & Understanding metacognition & $\begin{array}{l}\text { - Using metacognitive online reading } \\
\text { strategies } \\
\text { - Looking for specific information }\end{array}$ \\
\hline 5 & Impact of MORS on ORD & - Existence of impact \\
\hline 6 & Implementing MORS & $\begin{array}{ll}\text { - } & \text { Support strategies } \\
\text { - } & \text { Problem-solving strategy } \\
\text { - } & \text { Global strategy }\end{array}$ \\
\hline
\end{tabular}

Occurring Online Reading Dispositions

In this regard, students' responses were mostly similar. The most frequent dispositions reported by respondents were reflective. Abdullah said,

"While reading online, I try to find information in different ways. If

one of the sources does not satisfy me, I would go to another source.

Therefore, I can move from a website to another which becomes more

interesting and simpler with different search engines.".

Faisal depicted himself, "I am a flexible person as I read fast to find the information quickly, without wasting time”. Besides flexibility, Sultan showed another disposition and that is reflection. According to him, "The most occurring dispositions I show while reading online are reflection and persistence. They allow me to learn new things and skills." Ahmad had a similar report, "I am fast in reading and would show some kind of reflection and flexibility.".

Views on Online Reading Dispositions

Regarding this code, students' views were different. Khalid's point of view related to online reading dispositions is that they are helpful "They are okay with me since they help me in my study." The similarity between Faisal's and Sultan's point of view is worth mentioning, as they revealed that their skills need further development, "I need to develop my online reading skills" and "I need to develop my skills in order to develop my online reading dispositions," respectively.

Ahmad's reflection was different since he acknowledged that some of his colleagues faced difficulties in employing these dispositions, while others considered them easy: "Some students find it difficult and others find it easy, and for me, it is not difficult."

\section{Alternatives to Online Reading Dispositions}

When respondents were asked about having alternatives in case one of the online reading dispositions fails to achieve the task, they responded with certain ways to overcome this 
Arab World English Journal (AWEJ) Special Issue on Covid 19 Challenges April 2021

The Impact of Metacognitive Online Reading Strategies on Online Reading

Yaghi

obstacle. Khalid said, "If one of those online reading dispositions fail, I would search other websites to find more specific information. In case of an unsatisfactory answer, I will ask my friend to help me". On the other hand, Abdullah had a different view, he keeps switching between different websites to reach the answer; however, he does not ask for assistance from his colleagues as he is the one who always offers help,

"In the case that one of my dispositions fail or does not achieve my purpose of online reading, I will search different sources, like Youtube or Wikipedia, or switch between different sources to check the information. I rarely go to books. Personally, I am the one who offers the help, and I don't like to receive any help from others."

Faisal and Sultan had approximately similar responses to this point. Faisal described himself as being persistent and that he would read the text again, unless the text was difficult, in which case he will ask for his friend's aid. "In case of one of my online reading dispositions failing, I will read the text again, and if it is difficult, I might ask my friend for assistance. I can chat or WhatsApp him". Along the same lines, Sultan said, "If one of these dispositions fails, I will employ persistence, such as reading the text again, or I might show collaboration by calling and asking my friend to give me assistance."

Ahmad's answer was a little bit short and direct, although similar. According to him, "If one of these ORDS fails, I will try different things, like reading it again in order to get the main idea." He thinks that rereading the text would be useful and fruitful and might help the reader grasp the main idea.

\section{Understanding Metacognition}

All students have shown a full consensus about employing metacognitive online reading strategies while they read online. For example, Ahmad said "It is a great question. I use some strategies in order not to consume time, like highlighting the main ideas and details after printing the materials." Moreover, Abdullah valued the usefulness of metacognitive online reading strategies while using the Internet. According to him, "Online reading strategies are very important to me while surfing the Internet.".

\section{Impact of MORS on ORD}

In this regard, the overwhelming majority of students agreed that metacognitive online reading strategies have an impact on online reading dispositions. For instance, Sultan said "MORS have an impact on dispositions because they are related to the task; therefore, I will be fast and flexible to achieve my goals.". Moreover, there is a great impact of MORS on ORD as was stated by Ahmad

"MORS have a great impact on ORD since it motivates me to get a high score and assisted me to get the main idea in a very short time. Sometimes, I got panicked when I look at a long article, consequently, I utilize problem-solving strategies."

A clear difference has been reported by Khalid, "Honestly, I don't think that there is an impact of MORS on ORD”

\section{Suitability of MORS}

The most frequently used strategies reported by students belonged to support strategies and global categories. They attributed this selection to their academic status and level of English; therefore, those two kinds of strategies are the most suitable. Sultan said, "Support strategies and global strategies are the most suitable for me because most of my colleagues are not good enough in English and they need to use a dictionary to understand the new words.". Nevertheless, Ahmad was the only student who thought that problem -solving strategies are more appropriate and helpful "Problem-solving strategies are the most suitable for me." 
Arab World English Journal (AWEJ) Special Issue on Covid 19 Challenges April 2021

The Impact of Metacognitive Online Reading Strategies on Online Reading

Yaghi

\section{Discussion}

Based on the responses of the surveyed students, it can be noted that they showed different and varied dispositions. Hence, the findings revealed that students tend to manifest dispositions of flexibility more than other dispositions. By contrast, their least frequent dispositions were distributed between collaboration, critical stances, and reflection types. These findings are a little bit different from those of other studies conducted in this field. The following will give insights about the differences between this current study and other research.

Coiro (2003) has found that successful online readers have an ability to deal with daily updates that occur in the texts. She also mentioned that those skillful online readers show different dispositions during online reading including persistence, flexibility, and patience. In addition, they display creativity and confidence while using the Internet to comprehend diverse online texts.

In a study conducted by Tsai and Tsai (2003), it was found that school students with higher internet self -adequacy utilized PCs more accurately and productively, settling issues autonomously as opposed to requesting help. Correspondingly, they were more able to criticize and evaluate the information they experienced on the Internet.

One of the most important studies that has directly addressed this issue is the study of (O'Byrne \& McVerry, 2009), who created and steered an instrument to inspect online reading dispositions, which they depicted as "attitudes and beliefs that lead to the pattern of behavior that promotes gains in the acquisition of knowledge." The study has discovered three factors, reflection, persistence, and collaboration, which were noteworthy in the advancement of online reading dispositions. (O'Byrne \& McVerry, 2009) conducted further research in order to find more online reading dispositions that might occur while students are engaged in online reading. In the same line, Yaghi and Abdullah (2020), have discussed the online reading dispositions, and the outcomes are consistent with the current study, in which most occurring dispositions belong to reflection category.

In contrast to the current study, (Hooper \& Herath, 2014) have conducted a research where they aimed to investigate the changes on behaviors of online readers. The most striking result in their study was the respondents' answering that there was a change in their patience due to the large amount of reading material which highly pressured them and negatively impacted their patience.

The purpose of this study was to investigate the impact of metacognitive online reading strategies on online reading dispositions. Therefore, based on the students' responses to the OSOR questionnaire and interviews, an image of this relationship has emerged. The following paragraph will comprehensively discuss the results and shed light on the previous studies.

The analysis of this current study has revealed interesting results. Students' responses in the questionnaire have reflected their tendency to employ online support reading strategies. However, the variances of the mean scores among the three different strategies were not significant. There were slight differences since they stemmed from varying students and levels. The findings of this study were found to be consistent with those of a study conducted by Taki 
(2016), who found that Iranian students preferred to use support and problem-solving strategies while reading online in a second language. similarly, Vaičiūnienė and Užpalienè (2013) pointed out that students had a preference for using support and problem-solving strategies in online reading. In the same vein, H.-c. Huang, Chern, and Lin (2009) have reported the prevalence of using support strategies which has contributed to most comprehension gain. This study is also consistent with the study by S.-H. Huang (1999) and Shen and Min (2003), who also reported the dominance of support strategies among students. It is apparent that learners essentially rely on support strategies, such as translating, using dictionaries, or highlighting, to facilitate comprehension. The prevailing utilization of support strategies might be explained by convenience and the immediate feedback that students receive when utilizing them (Mokhtari \& Reichard, 2004). For instance, students can use the translation mechanism to decode long articles into L1 within a few seconds. Obviously, support reading strategies saves both time and effort, and they are useful for learners who are scared by large online articles. In an online reading environment of extensive information resources, learners are probably going to acknowledge and adopt strategies that can enable them to discover, assess, and utilize information quickly (H.-c. Huang et al., 2009; Leu, Kinzer, Coiro, \& Cammack, 2004).

In contrast to these findings, Shang (2016) studied EFL usage of metacognitive online reading strategies, and found that students valued the use of global reading strategies. Along the same lines, Ramli, Darus, and Bakar (2011) have found that ESL learners tend to employ global strategies more than other online reading strategies.

It is apparent that the most repeatedly used strategies were limited between support strategies and global strategies. Out of the top five used strategies, three strategies belong to the support category. This provides additional support for the study conducted by (Ramli et al., 2011).

Overall, the learners who participated in this study reported that they employ a wide range of metacognitive strategies when reading academic online texts. Therefore, it is important to point out that the most frequent strategy was "When reading online, I decide what to read closely and what to ignore." This result highlights the usefulness of online reading by giving online readers the flexibility to pick the text to read and neglect what they dislike. On the other hand, the least employed strategy was "I scan the online text to get a basic idea of whether it will serve my purposes before choosing to read it." The most widely used strategy among global reading strategies is "I try to picture or visualize information to help remember what I read online." Among problem-solving strategies, the most popular strategy is "I think about whether the content of the online text fits my reading purpose."

On the other hand, students have reported their preference to use tables, figures, and pictures in the online text to increase their understanding as the most employed support strategy. Students' points of view in interviews have confirmed the findings of the quantitative phase. They revealed their preference for utilizing support and global strategies, except for one student, who had a predilection to use problem-solving strategies more than the other.

In compliance with the impact of metacognitive online reading strategies on online reading dispositions, the study confirms that there is an impact through this relationship. The 
findings demonstrate that support reading strategies have the most significant impact on online reading dispositions.

After discussing the frequency of the three online reading strategies, this study highlights the impact of the metacognitive online reading strategies on online reading dispositions. The data analysis process demonstrates that reading strategies have an impact on the students' behavior while reading on the Internet. The current study lends support to previous findings in the literature. For example, Castek, Coiro, Henry, Leu, and Hartman (2015) revealed that students' tendencies and dispositions are firmly connected and affected by employing efficient reading strategies and skills that are required for online texts. Leu et al. (2004) have found that online readers need to utilize metacognitive strategies to locate and evaluate information while reading online texts. Another study by (McEneaney, 2003) also mentioned that dispositions while reading online texts would lead the reader to employ different metacognitive strategies to achieve the tasks.

\section{Conclusion}

The findings of this study seem very supportive of the impact of metacognitive online reading strategies on online reading dispositions of students/online readers. It can be said that metacognitive online reading strategies are tools used by online readers to fulfil multiple tasks, and their usage will vary according to the students' level, the genre of online texts and the tasks that ought to be completed at the end.

\section{Acknowledgement}

Dr. Eyhab T. Yaghi would like to thank the Deanship of Scientific Research at Majmaah University, Kingdom of Saudi Arabia, for funding this work under project number No. R-202180 .

\section{About the author}

Dr. Eyhab T. Yaghi is an assistant professor in TESOL in English department in The Deanship of Common First Year at Majmaah University. His research interests focus on different aspects related to metacognition and disposition of EFL learners and the intervention of technology with EFL classes. ORCiD: https://orcid.org/0000-0003-4462-6366

\section{References}

Anderson, N. J. (2003). Scrolling, clicking, and reading English: Online reading strategies in a second/foreign language. The Reading Matrix, 3(3).

Boggiano, A. K., Main, D. S., \& Katz, P. A. (1988). Children's preference for challenge: The role of perceived competence and control. Journal of personality and social psychology, 54(1), 134.

Carr, M., \& Claxton, G. (2002). Tracking the development of learning dispositions. Assessment in Education: Principles, Policy \& Practice, 9(1), 9-37.

Castek, J., Bevans-Mangelson, J., \& Goldstone, B. (2006). Reading adventures online: Five ways to introduce the new literacies of the Internet through children's literature. The Reading Teacher, 59(7), 714-729.

Castek, J., Coiro, J., Henry, L. A., Leu, D. J., \& Hartman, D. K. (2015). Research on instruction and assessment in the new literacies of online research and comprehension. Comprehension instruction: Research-based best practices, 324-344. 
Arab World English Journal (AWEJ) Special Issue on Covid 19 Challenges April 2021

The Impact of Metacognitive Online Reading Strategies on Online Reading

Yaghi

Claxton*, G., \& Carr, M. (2004). A framework for teaching learning: the dynamics of disposition. Early years, 24(1), 87-97.

Coiro, J. (2003). Exploring literacy on the internet: Reading comprehension on the internet: Expanding our understanding of reading comprehension to encompass new literacies. The Reading Teacher, 56(5), 458-464.

Coiro, J. (2007). Exploring changes to reading comprehension on the Internet. Paradoxes and possibilities for diverse adolescent readers (Thesis doctoral). University of Connecticut, Rhode Island, US.

Coiro, J. (2009). Rethinking online reading assessment. Educational Leadership, 66(6), 59-63.

Dewi, K. S., \& Sahiruddin, S. J. S. B. N. (2020). Online Reading Culture among Indonesian EFL Students at Tertiary Education Level. 4(2), 104-117.

Eagleton, M., \& Dobler, E. (2007). Reading the Web: strategies forInternet inquiry. In: New York: Guilford Press.

Fitzgerald, M. A. (2000). Critical thinking 101: The basics of evaluating information. Knowledge Quest, 29(2), 13.

Hair Jr, J. F., Hult, G. T. M., Ringle, C., \& Sarstedt, M. (2016). A primer on partial least squares structural equation modeling (PLS-SEM): Sage Publications.

Hooper, V., \& Herath, C. (2014). Is Google Making Us Stupid? The Impact of the Internet on Reading Behaviour. Paper presented at the Bled eConference.

Huang, H.-c., Chern, C.-1., \& Lin, C.-c. (2009). EFL learners' use of online reading strategies and comprehension of texts: An exploratory study. Computers \& Education, 52(1), 1326.

Huang, S.-H. (1999). A descriptive study of reading strategies used by Taiwanese EFL university more and less proficient readers.

Hurmerinta-Peltomäki, L., \& Nummela, N. (2006). Mixed methods in international business research: A value-added perspective. Management International Review, 46(4), 439459.

Lawless, K. A., \& Schrader, P. (2008). Where do we go now? Understanding research on navigation in complex digital environments. Handbook of research on new literacies, 267-296.

Leu, D. J., Castek, J., Hartman, D., Coiro, J., Henry, L., Kulikowich, J., \& Lyver, S. (2005). Evaluating the development of scientific knowledge and new forms of reading comprehension during online learning. Final report presented to the North Central Regional Educational Laboratory/Learning Point Associates. Retrieved May, 15, 2006.

Leu, D. J., Kinzer, C. K., Coiro, J. L., \& Cammack, D. W. (2004). Toward a theory of new literacies emerging from the Internet and other information and communication technologies. Theoretical models and processes of reading, 5(1), 1570-1613.

Marboot, K., Roohani, A., \& Mirzaei, A. J. I. i. L. T. (2020). Investigating Iranian EFL students' metacognitive online reading strategies, critical thinking, and their relationship: A mixed-methods study. 9(1), 151-182.

McEneaney, J. E. (2003). Does hypertext disadvantage less able readers? Journal of Educational Computing Research, 29(1), 1-12.

Mokhtari, K., \& Reichard, C. (2004). Investigating the strategic reading processes of first and second language readers in two different cultural contexts. System, 32(3), 379-394. 
Arab World English Journal (AWEJ) Special Issue on Covid 19 Challenges April 2021

The Impact of Metacognitive Online Reading Strategies on Online Reading

Yaghi

O'Byrne, W. I., \& McVerry, J. G. (2009). Measuring the dispositions of online reading comprehension: A preliminary validation study. Paper presented at the National Reading Conference Yearbook.

Ramli, N. F. M., Darus, S., \& Bakar, N. A. (2011). Metacognitive online reading strategies of adult ESL learners using a learning management system. Theory and Practice in Language Studies, 1(3), 195-204.

Shang, H.-F. (2016). Online Metacognitive Strategies, Hypermedia Annotations, and Motivation on Hypertext Comprehension. Journal of Educational Technology \& Society, 19(3).

Shen, Y.-s., \& Min, H.-T. (2003). A study of the effects of two text structures on Taiwanese EFL junior high school students strategy use. Unpublished master's thesis, National Cheng Kung University, Tainan, Taiwan.

Sheorey, R., \& Mokhtari, K. (2001). Coping with academic materials: differences in the reading strategies of native and non-native readers. System, 29(4), 431-449.

Taki, S. (2016). Metacognitive online reading strategy use: Readers' perceptions in L1 and L2. Journal of Research in Reading, 39(4), 409-427.

Tate, M., \& Alexander, J. (1996). Teaching critical evaluation skills for World Wide Web resources. Computers in libraries, 16(10).

Tsai, M.-J., \& Tsai, C.-C. (2003). Information searching strategies in web-based science learning: The role of Internet self-efficacy. Innovations in education and Teaching International, 40(1), 43-50.

Vaičiūnienè, V., \& Užpalienè, D. (2013). Metacognitive online reading strategies in foreign language learning context at university. Social Technologies, 3(2), 316-329.

Yaghi, E., \& Abdullah, A. (2020). Understanding Online Reading Dispositions from the Perspective of Saudi EFL Learners.

Zawilinski, L., Carter, A., O’Byrne, I., McVerry, G., Nierlich, T., \& Leu, D. J. (2007). Toward a taxonomy of online reading comprehension strategies. Paper presented at the 57rd Annual Meeting of the National Reading Conference (Austin, TX). 